\title{
Penerapan Jaringan Saraf Tiruan untuk Mengukur Korelasi Beban Kerja Dosen Terhadap Peningkatan Jumlah Publikasi
}

\author{
Putrama Alkhairi' ${ }^{1}$, Irfan Sudahri Damanik ${ }^{3}$, Agus Perdana Windarto ${ }^{2}$ \\ 1,2,3 Program Studi Sistem Informasi, STIKOM Tunas Bangsa,Pematangsiantar,Indonesia \\ Jl.Jend.Sudirman Blok A-B No.1,2,3 Pematangsiantar,21127,Indonesia \\ E-mail: putramaalkhairi97@gmail.com,irfan.sudahri@amiktunasbangsa.ac.id \\ ,agus.perdana@amiktunasbangsa.ac.id
}

\begin{abstract}
One important point in carrying out the functions of the Tridharma of Higher Education by lecturers is to carry out research and publish the results of their thoughts and analyzes. The demands of publication by the academic community of Higher Education have a considerable impact on the awareness of the lecturers of the importance of conducting studies, research and writing scientific works. The development of scientific work in Indonesia has been relatively better, especially since the enactment of government regulations, which required S1, S2 and S3 students to write articles in scientific journals as one of the prerequisites for graduation. Lecturers certainly have greater demands to actively write in scientific journals both at accredited national level and reputable international journals. So the authors conducted this study aimed at analyzing the correlation of the level of lecturer workload to the increase in the number of publications. STIKOM Tunas Bangsa does not yet have a system to analyze the level of lecturer workload with an increase in the number of studies. For this reason, it is necessary to apply the Backpropagation algorithm. ANN combined with the Backpropagation algorithm can measure the level of correlation. The variables used are structural positions, number of even and odd semester credits, number of services. The target used is the amount of research. So the pattern of correlation between the two variables is formed. The output of the lecturer workload is reduced by the target which is the number of publications. So the results obtained are correlations between lecturers' workloads to the increase in the number of publications.
\end{abstract}

Keywords: Lecturer, Publication, Correlation, Backpropagation, Artificial Neural Networks

Abstrak - Salah satu poin penting dalam menjalankan fungsi Tridharma Perguruan Tinggi oleh dosen adalah melaksanakan penelitian dan mempublikasikan hasil pemikiran serta analisisnya tersebut. Tuntutan publikasi yang dilakukan komunitas akademik Perguruan Tinggi memberikan dampak yang cukup besar terhadap kesadaran para dosen pentingnya melakukan kajian, penelitian serta menulis karya ilmiah. Perkembangan karya ilmiah di Indonesia relatif makin baik, terutama sejak diberlakukannya regulasi pemerintah, yang mewajibkan mahasiswa S1, S2 hingga S3 untuk menulis artikel di jurnal ilmiah sebagai salah satu prasyarat kelulusan. Dosen tentunya semakin besar tuntutannya untuk aktif menulis di jurnal ilmiah baik ditingkat nasional terakreditasi maupun jurnal internasional bereputasi. Maka penulis melakukan penelitian ini bertujuan untuk menganalisa korelasi tingkat beban kerja dosen terhadap peningkatan jumlah publikasi. STIKOM Tunas Bangsa belum memiliki sistem untuk menganalisa tingkat beban kerja dosen dengan peningkatan jumlah penelitian. Untuk itu perlu diterapkan algoritma Backpropagation. JST dipadukan dengan algoritma Backpropagation mampu mengukur tingkat korelasi. Variabel yang digunakan adalah jabatan struktural, jumlah sks semester genap dan ganjil, jumlah pengabdian. Target yang digunakan adalah jumlah penelitian. Maka terbentuklah pola korelasi kedua variabel tersebut. Hasil output jst beban kerja dosen dikurang dengan 
target yang menjadi jumlah publikasi. Sehingga hasil yang didapat adalah korelasi antara beban kerja dosen terhadap peningkatan jumlah publikasi.

Kata kunci: Dosen, Publikasi, Korelasi, Backpropagation, Jaringan saraf tiruan

\section{PENDAHULUAN}

Jaringan saraf tiruan (JST) pada dasarnya merupakan fungsi model matematika yang mendefinisikan fungsi $\mathrm{f}$ : X - Y. Jaringan saraf tiruan termasuk sistem kecerdasan buatan yang merupakan dalam usahanya menirukan intelegensi manusia, belum mengadakan pendekatan dalam bentuk fisiknya melainkan dari sisi yang lain[1]. Jaringan saraf tiruan adalah paradigma pengolahan informasi yang terinspirasi oleh sistem Saraf secara biologis, seperti proses informasi pada otak manusia[1]. Elemen kunci dari paradigma ini adalah struktur dari system pengolahan informasi yang terdiri dari sejumlah besar elemen pemrosesan yang saling berhubungan, bekerja serentak untuk menyelesaikan masalah tertentu. Cara kerja JST seperti cara kerja manusia. Sebuah JST dikonfigurasikan untuk aplikasi tertentu, seperti pengenalan pola atau aplikasi data. Ada banyak teknik yang dapat digunakan untuk implementasi Jaringan saraf tiruan yaitu Perceptron dan Backpropagation[2]. Dalam penelitian ini penulis menggunakan algoritma Backpropagation. Backpropagation algoritma penurunan gradient untuk meminimilkan kuadrat error keluaran. Ada tiga tahap yang harus dilakukan dalam pelatihan jaringan, yaitu tahap perambatan maju (forward propagation), tahap perambatan balik, dan tahap perubahan bobot dan bias. Arsitektur jaringan ini tediri dari input layer, hidden layer, dan output layer [3].

Algoritma Backpropagation merupakan salah satu algoritma yang sering digunakan dalam menyelesaikan masalah-masalah yang rumit. Hal ini dimungkinkan karena jaringan dengan algoritma ini dilatih dengan menggunakan algoritma belajar terbimbing[4]. Algoritma Backpropagation merupakan algoritma yang tepat untuk digunakan, karena mampu untuk menyelesaikan permasalahan yang kompleks dengan nilai error terkecil, maka penulis dalam mengukur tingkat korlasi beban kerja dosen terhadap peningkatan jumlah publikasi menggunakan algoritma Backpropagation[5]. Dosen menurut Undang-Undang Guru dan Dosen nomor 14 tahun 2005 adalah tenaga pendidik profesional dan ilmuwan dengan tugas utama mentransformasikan mengembangkan dan menyebarluaskan ilmu pengetahuan, teknologi, seni budaya melalui pendidikan, penelitian dan pengabdian pada masyarakat sesuai dengan isi tridharma perguruan tinggi. Tugas seorang dosen adalah melaksanakan tridharma perguruan tinggi dengan beban kerja paling sedikit 12 (dua belas) SKS dan paling banyak 16 (enam belas) SKS pada setiap semester sesuai dengan kualifikasi akademik. Dengan ketentuan tugas melakukan pengajaran dan penelitian paling sedikit 9 (sembilan) SKS persemester, sedangkan tugas melakukan pengabdian kepada masyarakat dapat dilaksanakan melalui kegiatan pengabdian kepada masyarakat yang diselenggarakan oleh perguruan tinggi yang bersangkutan atau melalui lembaga lain sesuai dengan peraturan perundang - undangan dengan hasil luaran berupa publikasi ilmiah, setiap dosen wajib memiliki luaran publikasi pada setiap tahunnya[6]. 
Publikasi ilmiah merupakan elemen penting dalam dunia pendidikan. Riset dan publikasi ilmiah ibarat dua sisi mata uang yang tidak dapat dipisahkan. Hasil riset ilmiah yang tidak dipublikasikan hanya akan menjadi tumpukan dokumen yang mengisi sudut ruang perpustakaan[7]. Hasil riset ilmiah di perguruan tinggi harus dipublikasikan, sehingga riset tersebut memiliki makna lebih dan memberikan sumbangsih bagi penyebaran ilmu pengetahuan dan meningkatkan nilai akreditasi instansi perguruan tinggi. Maka meningkatkan publikasi pada sebuah di sivitas akademik merupakan hal yang menjadi salah satu prioritas utama[8]. STIKOM Tunas Bangsa merupakan salah satu perguruan tinggi swasta di indonesia yang bergerak dibidang ilmu komputer. STIKOM Tunas Bangsa memiliki visi menjadi sekolah tinggi yang unggul di bidang ilmu komputer dalam tatanan global pada tahun 2025. Untuk mewujudkan hal tersebut, semua komponen harus bekerja sama. Salah satunya adalah peran seorang tenaga pendidik profesional di perguruan tinggi tersebut. Kualitas sumber daya dosen ditentukan oleh jumlah luaran berupa publikasi ilmiah karena hal ini dapat meningkatkan ilmu pengetahuan dan keterampilan dosen tersebut serta meningkat nilai akreditasi perguruan tinggi. Minimnya minat dosen dalam melakukan publikasi ilmiah merupakan masalah bagi perguruan tinggi, karena hal ini berdampak pada kualitas dari seorang dosen. Saat ini STIKOM Tunas bangsa menduduki peringkat 344 dari total 4576 perguruan tinggi yang ada di Indonesia versi kemenristek dikti tahun 2018 di tinjau dari empat unsur, yaitu kualitas publikasi jurnal, kualitas publikasi conference, kualitas HKI dan kualitas buku. Berdasarkan data tersebut perlu ada peningkatan jumlah publikasi di STIKOM Tunas Bangsa. Faktor yang mempengaruhi minimnya minat dosen dalam melakukan jumlah publikasi, tercermin dari produktivitas pelaksanaan tridarma perguruan tinggi. Saat ini STIKOM Tunas Bangsa belum memiliki sistem yang mampu menganalisa korelasi beban kerja dosen terhadapat peningkatan jumlah publikasi [6].

Berdasarkan studi literatur yang telah dilakukan, bahwa algoritma Jaringan saraf tiruan telah banyak diterapkan dalam penelitian, diantaranya dapat dilihat dalam penelitian yang dilakukan oleh Pangastuti. Penelitian tersebut menggunakan algoritma Jaringan saraf tiruan Backpropagation untuk mengukur tingkat korelasi prestasi mahasiswa. Berdasarkan hasil penelitian tersebut, tingkat korelasi kecocokan antara target yang telah ditentukan dan target hasil prediksi sebesar 61\% [8]. Berdasarkan uraian diatas, maka Penulis mengangkat judul "Penerapan Jaringan saraf tiruan Untuk Mengukur Korelasi Beban Kerja Dosen Terhadap Peningkatan Jumlah Publikasi". Diharapakan penelitian ini dapat memberikan manfaat kepada institusi dilingkungan STIKOM Tunas Bangsa dengan menganalisa korelasi hubungan antara beban kerja dosen terhadap peningkatan jumlah publikasi yang berdampak pada meningkatnya nilai akreditasi institusi.

\section{METODOLOGI PENELITIAN}

\subsection{Identifikasi Masalah}

Identifikasi masalah merupakan sekelompok aspek yang berada disekitar masalah utama yang dapat diteliti untuk menjawab permasalahan utama. Adapun permasalahan yang dapat diidentifikasi untuk pelaksanaan seminar ini adalah perhitungan yang masih manual 


\subsection{Metode Pengumpulan Data}

Pengumpulan data merupakan proses pengadaan data primer, untuk kebutuhan suatu penelitian. Adapun teknik pengumpulan data dalam penelitian ini yaitu : [9]

a. Penelitian Kepustakaan (Library Research) yaitu memanfaatkan perpustakaan sebagai sarana dalam mengumpulkan data, dengan mempelajari buku - buku , jurnal - jurnal sebagai bahan referensi. Hal ini dilakukan dengan membaca tulisan berupa buku dan jurnal yang berkaitan dengan kasus yang penulis angkat.

b. Penelitian Lapangan (Field Work Research) yaitu penelitian yang dilakukan secara langsung dilapangan dengan menggunakan beberapa teknik sebagai berikut:

1. Observasi adalah metode pengumpulan data dengan cara mengadakan pengamatan langsung terhadap berbagai kegiatan yang ada. Hal ini penulis lakukan dengan melakukan pengamatan langsung di lokasi penelitian guna mencari data-data yang diperlukan dalam penelitian ini seperti pengambilan jumlah publikasi ilmiah dan beban kerja dosen yang akan diuji.

2. Wawancara adalah proses pengumpulan data atau informasi melalui tatap muka antara pihak penanya (interviewer) dengan pihak yang ditanya atau penjawab (interviewee). Hal ini penulis lakukan dengan bertanya langsung kepada pihak-pihak yang berkompeten seperti LPPM (Lebaga Penelitian dan Pengabdian Masyarakat) dan bagian Biro Akademik STIKOM Tunas Bangsa Pematangsiantar. Data yang dikumpulkan adalah, jumlah sks yang diampu dosen, jumlah penelitian, jumlah pengabdian, dan jabatan struktural.

3. Studi Literatur Setelah masalah dalam penelitian dianalisa, langkah selanjutnya yang dilakukan peneliti adalah melakukan studi literatur, yaitu membandingkan algoritma perhitungan yang telah dilakukan oleh peneliti sebelumnya kelemahan dan keunggulan dari algoritma yang saya gunakan.

\subsection{Tinjauan Pustaka}

\subsubsection{Kecerdasan Buatan}

Kecerdasan Buatan atau Intelegensi Artifisial (bahasa Inggris: Artificial Intelligence atau hanya disingkat $A I$ ) didefinisikan sebagai kecerdasan entitas ilmiah[10]. Sumbangan terbesar di bidang AI diawali oleh tulisan dari Alan Turing pada tahun 1950 berjudul Computing Machinery and Intelligence mendiskusikan syarat sebuah mesin di anggap cerdas. Kecerdasan yang dimaksud di sini merujuk pada mesin yang mampu berpikir, menimbang tindakan yang akan diambil dan mampu mengambil keputusan seperti yang dilakukan manusia. Kecerdasan buatan diciptakan dan dimasukkan ke dalam suatu mesin (komputer) agar dapat melakukan pekerjaan seperti yang dapat dilakukan manusia. Beberapa macam bidang yang menggunakan kecerdasan buatan antara lain sistem pakar, permainan komputer (games), logika fuzzy, Jaringan saraf tiruan dan Robotika [11], [1].

\subsubsection{Definisi Jaringan saraf tiruan}


Jaringan saraf tiruan (JST) (artificial neural network (ANN) / simulated neural network (SNN) / neural network(NN)) merupakan jaringan yang terdiri atas sekelompok unit pemroses kecil yang dimodelkan berdasarkan jaringan saraf manusia [10], [3]. JST tercipta sebagai suatu generalisasi model matematis dari pemahaman manusia (human cognition) yang didasarkan atas asumsi pemerosesan informasi terjadi pada elemen sederhana yang disebut neuron, sinyal mengalir diantara sel saraf/neuron melalui suatu sambungan penghubung, setiap sambungan penghubung memiliki bobot yang bersesuaian [12]. Bobot ini untuk menggandakan/ mengalihkan sinyal yang dikirim, setiap sel saraf akan menerapkan fungsi aktivasi terhadap sinyal hasil penjumlahan berbobot yang masuk kepadanya untuk mennetukan sinyal keluarannya[1].

\subsection{Model Jaringan Backpropagation}

Model jaringan Backpropagation merupakan suatu teknik pembelajaran atau pelatihan supervised leaning yang paling banyak digunakan. Algoritma ini merupakan salah satu algoritma yang sangat baik dalam menangani masalah pengenalan pola-pola kompleks[13], [12]. Didalam jaringan Backpropagation, setiap unit yang berada di lapisan input berhubungan dengan setiap unit yang ada di lapisan tersembunyi. Setiap unit yang ada di lapisan tersembunyi terhubung dengan setiap unit yang ada di lapisan output. Jaringan ini terdiri dari banyak lapisan (multilayer network). Ketika jaringan ini diberikan pola masukan sebagai pola pelatihan, maka pola tersebut menuju unit-unit lapisan tersembunyi untuk selanjutnya diteruskan pada unit-unit dilapisan keluaran. Kemudian unit-unit lapisan keluaran akan memberikan respon sebagai keluaran jaringan saraf tiruan. Saat hasil keluaran tidak sesuai dengan yang diharapkan, maka keluaran akan disebarkan mundur (backward) pada lapisan tersembunyi kemudian dari lapisan tersembunyi menuju lapisan masukan [14].

Tahap pelatihan ini merupakan langkah untuk melatih suatu jaringan saraf tiruan, yaitu dengan cara melakukan perubahan bobot, sedangkan penyelesaian masalah akan dilakukan jika proses pelatihan tersebut telah selesai, fase ini disebut fase pengujian.

$x^{1}=\frac{0.8(x-a)}{b-a}+0.1$

\subsubsection{Arsitektur Jaringan Backpropagation}

Setiap unit dari layer input pada jaringan Backpropagation selalu terhubung dengan setiap unit yang berada pada layer tersembunyi, demikian juga setiap unit layer tersembunyi selalu terhubung dengan unit pada layer output [1]. Jaringan Backpropagation terdiri dari banyak lapisan (multilayer network) yaitu:

a. Lapisan input (1 buah), yang terdiri dari 1 hingga $\mathrm{n}$ unit input .

b. Lapisan tersembunyi (minimal 1 buah), yang terdiri dari 1 hingga $p$ unit tersembunyi.

c. Lapisan output (1 buah), yang terdiri dari 1 hingga m unit output. 


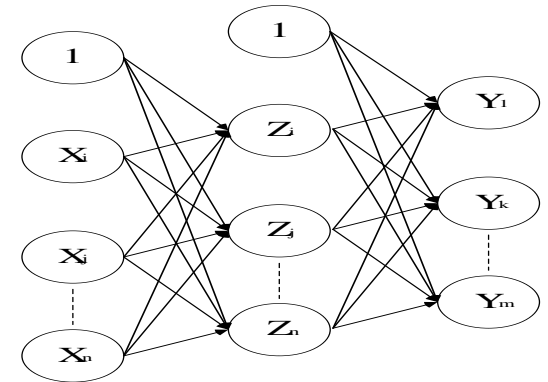

Gambar 1. Arsitektur Jaringan Backpropagation

(Sumber : Budiharto \& Suhartono, 2014)

\subsubsection{Pelatihan Jaringan Backpropagation}

Aturan pelatihan jaringan Backpropagation terdiri dari 2 tahapan, feedforward dan backward propagation. Pada jaringan diberikan sekumpulan contoh pelatihan yang disebut set pelatihan. Set pelatihan ini digambarkan dengan sebuah vektor feature yang disebut dengan vektor input yang diasosiasikan dengan sebuah output yang menjadi target pelatihannya. Dengan kata lain set pelatihan terdiri dari vektor input dan juga vektor output target. Keluaran dari jaringan berupa sebuah vektor output aktual. Selanjutnya dilakukan perbandingan antara output aktual yang dihasilkan dengan output target dengan cara melakukan pengurangan diantara kedua output tersebut. Hasil dari pengurangan berupa Error - Error dijadikan sebagai dasar dalam melakukan perubahan dari setiap bobot dengan mempropagationkannya kembali[13].

Setiap perubahan bobot yang terjadi dapat mengurangi Error. Siklus perubahan bobot (epoch) dilakukan pada setiap set pelatihan sehingga kondisi berhenti dicapai, yaitu bila mencapai jumlah epoch yang diinginkan atau hingga sebuah nilai ambang yang ditetapkan terlampaui [15], [12].

Algoritma pelatihan jaringan Backpropagation terdiri dari 3 tahapan yaitu:

a. Tahap umpan maju (feedforward).

b. Tahap umpan mundur (Backpropagation).

c. Tahap pengupdatean bobot dan bias.

\subsubsection{Pengujian Jaringan Backpropagation}

Setelah bobot yang terbaik pada tahap pelatihan didapat, maka nilai pembobot tersebut digunakan untuk mengolah data masukan untuk menghasilkan keluaran yang sesuai. Hal ini digunakan untuk menguji apakah JST dapat bekerja dengan baik yaitu dapat memprediksi pola data yang telah dilatihkan dengan tingkat kesalahan yang kecil[13].

Notasi yang digunakan dalam algoritma pengujian:

$\mathrm{X}_{\mathrm{i}}$ : Unit input ke-i

$\mathrm{Z}_{\mathrm{j}}$ : Hidden unit ke-j

$\mathrm{Y}_{\mathrm{k}}$ : Unit output ke-k

$\mathrm{v}_{\mathrm{j}}$ : Bias untuk hidden unit ke-j

$\mathrm{v}_{\mathrm{ij}}$ : Bobot antara unit input ke-i dengan hidden unit ke-j

$\mathrm{w} 0 \mathrm{k}$ : Bias untuk unit output ke-k

$\mathrm{W}_{\mathrm{jk}}$ : Bobot antara hidden unit ke-j dengan unit output ke-k 
Step 1 : Inisialisasi Inisialisasi nilai bobot dan bias sesuai dengan bobot yang dihasilkan pada proses pelatihan

Step 2 : Setiap input $(\mathrm{Xi}, \mathrm{i}=1, \ldots, \mathrm{n})$ menyebarkan sinyal input pada seluruh hidden unit

Step 3 : Setiap hidden unit $(\mathrm{Zj}, \mathrm{j}=1, \ldots, \mathrm{p})$ akan menghitung sinyal-sinyal input dengan bobot dan biasnya.

$z_{i n_{j}}=v 0_{j}+\sum_{i=1}^{n} X_{i} V_{i j}$

Kemudian dengan menggunakan fungsi aktivasi yang telah ditentukan diperoleh sinyal output dari hidden unit tersebut.

$\mathrm{z}_{\mathrm{j}}=\mathrm{f}\left(\mathrm{z}_{-} \mathrm{in}_{\mathrm{j}}\right)$

Step 4 : Setiap unit output $(\mathrm{Yk}, \mathrm{k}=1, \ldots, \mathrm{m})$ akan menghitung sinyal-sinyal dari hidden unit dengan bobot dan biasnya.

$y_{-i n_{k}}=v 0_{k}+\sum_{j=1}^{p} Z_{j} W_{j k}$

Kemudian dengan menggunakan fungsi aktivasi yang telah ditentukan diperoleh sinyal output dari unit output tersebut.

$\mathrm{y}_{\mathrm{k}}=\mathrm{f}\left(\mathrm{y}_{-} \mathrm{in}_{\mathrm{k}}\right)$

\subsection{Pengertian Dosen}

Dosen adalah tenaga pendidik yang mempunyai peran sebagai penentu keberhasilan tujuan perguruan tinggi selain tenaga kependidikan lainnya, karena dosen yang langsung bersinggungan dengan peserta didik, untuk memberikan bimbingan yang muaranya akan menghasilkan lulusan sesuai seperti yang diharapkan. Untuk itu kinerja dosen harus selalu dikembangkan dan ditingkatkan. Upaya-upaya untuk meningkatkan kinerja itu dilakukan dengan berbagai cara, antara lain (1) memberikan peluang untuk berkembang dalam karir secara profesional, (2) memastikan adanya kesempatan untuk meningkatkan pengetahuan dan melanjutkan pendidikan ke strata yang lebih tinggi, (3) memberikan perhatian, penghargaan dan insentif, (4) menjamin adanya peluang untuk mengembangkan gaya kepemimpinan pembelajaran yang baik (5) adanya jaminan sosial yang baik dan (6) Meningkatkan jumlah publikasi guna menaikan nilai akreditasi institusi [6].

\subsection{Analisis Data}

Berdasarkan studi literatur yang telah dilakukan, bahwa algoritma Jaringan saraf tiruan telah banyak diterapkan dalam penelitian, diantaranya dapat dilihat dalam penelitian yang dilakukan oleh Pangastuti. Penelitian tersebut menggunakan algoritma Jaringan saraf tiruan Backpropagation untuk mengukur tingkat korelasi prestasi mahasiswa. Berdasarkan hasil penelitian tersebut, tingkat korelasi kecocokan antara target yang telah ditentukan dan target hasil prediksi sebesar $61 \%$ [8]. 
Metode analisis data terdiri atas dua macam, yaitu metode statistik deskriptif dan algoritma statistik inferensial. Jika pada Metode penelitian penulis menggunakan Metode penelitian kuantitatif, maka metode analisa data yang penulis gunakan adalah metode statistik inferensial.

Statistik inferensial adalah statistik yang berkaitan dengan analisis data (sampel), kemudian diambil kesimpulan yang digeneralisasikan kepada seluruh populasi. Analisis statistik inferensial dapat dikatakan sebagai algoritma analisis dengan menggunakan data yang berbentuk angka dan dianalisis dengan cara membandingkan melalui perhitungan dan mengaplikasikannya dengan cara menggunakan rumus yang sesuai. Analisis statistik inferensial digunakan untuk menguji parameter populasi data yang ada, dengan menggunakan data yang berasal dari responden [16].

Data yang digunakan sebagai instument penelitian dalam menghitung korelasi terdiri dari :

a. Jumlah SKS yang di ampuh dosen persemester

b. Jumlah penelitian

c. Jumlah pengabdian

d. Jabatan Struktural

Data parameter diatas akan diolah dan dianalisa menggunakan perhitungan algoritma Backpropagation untuk mengukur "seberapa kuat" atau "derajat kedekatan" suatu relasi yang terjadi antar variabel beban kerja dosen dengan peningkatan jumlah publikasi. Data diolah menggunakan Matlab yang berfungsi sebagai validasi dan reabilitas data untuk mencari keakuratan data. Data yang akurat maka akan dilakukan pengolahan data untuk mencari hasil dari masalah penelitian dengan menggunakan Matlab 6.1 dan mengambil keputusan dari hasil pengolahan data menggunakan Matlab 6.1 yang dilakukan.

\subsection{Algoritma Backpropagation}

Permasalahan yang sudah dianalisa, selanjutnya penulis mengukur tingkat korelasi beban kerja dosen terhadap peningkatan jumlah publikasi tersebut dengan menggunakan Jaringan saraf tiruan algoritma Backpropagation. Dalam algoritma Algoritma Backpropagation biasanya digunakan jaringan multilayer untuk meminimalkan error pada output yang dihasilkan oleh jaringan dengan adanya proses belajar dan pengujian data.

\subsubsection{Rancangan Penelitian}

Rancangan atau model penelitian disajikan dalam rancangan Flowchart pada gambar 3.1. : 


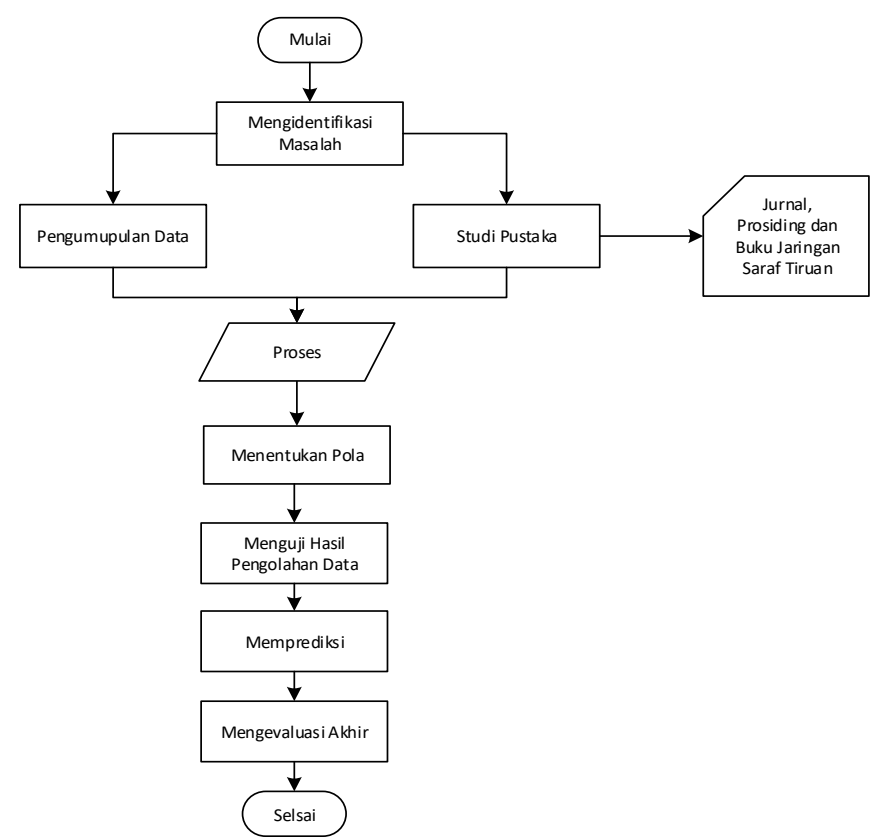

Gambar 2. Rancangan Penelitian

(Sumber : Wanto, 2017)

Gambar 3.1. menjelaskan rancangan penelitian yang dilakukan untuk mengukur korelasi beban kerja dosen terhadap peningkatan jumlah publikasi dengan menggunakan Algoritma Backpropagation yang terdiri dari :

a. Mengidentifikasi Masalah

Masalah yang terkait menganalisa korelasi beban kerja dosen terhadap peningkatan jumlah publikasi agar terlaksananya tridharma dosen dengan yang menghaslikan peningkatan luaran berupa publikasi ilmiah.

b. Pengumpulan Data

Pada tahap ini, data-data diperoleh dari pihak-pihak yang berkompeten LPPM (Lembaga Penelitian dan Pengabdian Masyarakat) dan Biro Akademik STIKOM Tunas Bangsa Pematangsiantar.

Pengolahan data dilakukan dengan bantuan Matlab 6.1 aplikasi perangkat lunak. Sampel Data adalah beban kerja dosen terhadap peningkatan jumlah publikasi yang dikelompokkan berdasarkan beban kerja dosen. Data ini akan digunakan pada data pelatihan dan data pengujian. Sampel data yang telah diproses dan ditranformasikan adalah sebagai berikut

Tabel 1. Data Beban Kerja Dosen Yang Telah Ditransformasikan

\begin{tabular}{|c|l|c|c|c|c|c|}
\hline No & \multicolumn{1}{|c|}{ Nama Dosen } & $\begin{array}{c}\text { Sks } \\
\text { Genap }\end{array}$ & $\begin{array}{c}\text { Sks } \\
\text { Ganjil }\end{array}$ & $\begin{array}{c}\text { Jabatan } \\
\text { Struktural }\end{array}$ & $\begin{array}{c}\text { Jumlah } \\
\text { Pengabdian }\end{array}$ & $\begin{array}{c}\text { Jumlah } \\
\text { Publikasi }\end{array}$ \\
\hline 1 & Agus Perdana Windarto, M.Kom & 22 & 24 & 1 & 8 & 64 \\
\hline 2 & Ahmad Fithrianto, S.Ag, M.A & 0 & 4 & 0 & 0 & 0 \\
\hline 3 & Alben Sigiro, S.Pd, M.Hum & 2 & 3 & 0 & 0 & 0 \\
\hline 4 & Amer Sharif, S.Si., M.Kom & 0 & 8 & 0 & 0 & 0 \\
\hline 5 & Anjar Wanto, M.Kom & 26 & 18 & 1 & 5 & 54 \\
\hline 6 & Asmarani, M.S.I & 0 & 4 & 0 & 0 & 0 \\
\hline 7 & Bahrudi Efendi Damanik, S.E, M.M & 0 & 6 & 0 & 2 & 0 \\
\hline 8 & Dameria Purba, S.T & 6 & 27 & 0 & 0 & 0 \\
\hline
\end{tabular}




\begin{tabular}{|c|c|c|c|c|c|c|}
\hline No & Nama Dosen & $\begin{array}{c}\text { Sks } \\
\text { Genap }\end{array}$ & $\begin{array}{c}\text { Sks } \\
\text { Ganjil }\end{array}$ & $\begin{array}{l}\text { Jabatan } \\
\text { Struktural }\end{array}$ & $\begin{array}{c}\text { Jumlah } \\
\text { Pengabdian }\end{array}$ & $\begin{array}{c}\text { Jumlah } \\
\text { Publikasi }\end{array}$ \\
\hline 9 & Dewi Kirana, S.E, M.M & 6 & 4 & 0 & 0 & 0 \\
\hline 10 & Dr. Dedy Hartama, S.T, M.KOM & 9 & 32 & 1 & 9 & 63 \\
\hline 11 & Drs. Nesar Achmad Khan, M.Pd & 8 & 10 & 0 & 0 & 0 \\
\hline 12 & Eka Irawan, M.Kom & 21 & 22 & 1 & 1 & 14 \\
\hline 13 & Eva Desiana, S.Kom., M.Kom & 0 & 18 & 0 & 0 & 0 \\
\hline 14 & Fitri Anggraini, M.Pd. & 4 & 14 & 0 & 1 & 4 \\
\hline 15 & Fitri Rizki, M.Pd & 6 & 14 & 0 & 1 & 4 \\
\hline 16 & Handrizal, S.Si., M.Comp.Sc & 6 & 3 & 0 & 2 & 2 \\
\hline 17 & Hasudungan Siahaan, S.Kom & 9 & 33 & 0 & 0 & 0 \\
\hline 18 & Hendry Qurniawan,S.Kom & 8 & 25 & 0 & 0 & 0 \\
\hline 19 & Heru Satria Tambunan, M.Kom & 23 & 18 & 1 & 1 & 5 \\
\hline 20 & Husnul Arifin S.Ag, S.Pd.I, M.Pd & 0 & 6 & 0 & 0 & 0 \\
\hline 21 & Ika Okta Kirana, M.Pd & 11 & 14 & 0 & 1 & 7 \\
\hline 22 & Ilham Syahputra Saragih, S.Sos, M.M & 16 & 24 & 1 & 0 & 1 \\
\hline 23 & Indra Gunawan, M.Kom & 26 & 24 & 1 & 1 & 19 \\
\hline 24 & Ir. Sufianto Mahfudz, M.Kom & 5 & 7 & 0 & 0 & 0 \\
\hline 25 & Irfan Sudahri Damanik, M.Kom & 25 & 19 & 1 & 2 & 8 \\
\hline 26 & Jalaluddin, S.Pd, M.Pd & 4 & 20 & 0 & 0 & 3 \\
\hline 27 & Jaya Tata Hardinata, M.Kom & 21 & 27 & 0 & 0 & 6 \\
\hline 28 & Khairil Anwar Uzir, S.H, S.Kom, M.Pd & 2 & 8 & 0 & 0 & 0 \\
\hline 29 & Letkol Inf Jon Heriko S.E, MM & 4 & 6 & 0 & 0 & 0 \\
\hline 30 & Lisnani, S.S., M.Pd & 2 & 4 & 0 & 0 & 0 \\
\hline 31 & M. Fauzan, M.E.I & 12 & 13 & 1 & 4 & 18 \\
\hline 32 & M. Safii, M.Kom & 4 & 10 & 1 & 3 & 0 \\
\hline 33 & Mawar Silalahi, S.Th, M.Pd.K & 0 & 10 & 0 & 0 & 0 \\
\hline 34 & Muhammad Zein, S.Pd.I, M.Pd.I & 0 & 6 & 0 & 0 & 0 \\
\hline 35 & Rafiqa Dewi, M.Kom & 8 & 25 & 0 & 0 & 0 \\
\hline 36 & Sahmi Purba, M.PdK & 0 & 4 & 0 & 0 & 0 \\
\hline 37 & Saifullah, M.Kom & 21 & 20 & 0 & 1 & 8 \\
\hline 38 & Sumarno, M.Kom & 26 & 27 & 1 & 1 & 11 \\
\hline 39 & $\begin{array}{l}\text { Victor Asido Elyakim Panggabean, } \\
\text { M.Kom }\end{array}$ & 4 & 14 & 1 & 0 & 0 \\
\hline 40 & Zulaini Masruro Nasution,S.Pd.I., M. Pd & 10 & 14 & 0 & 0 & 3 \\
\hline
\end{tabular}

\section{Keterangan :}

$\mathrm{X} 1$ = Sks Genap

$\mathrm{X} 2$ = Sks Ganjil

$\mathrm{X} 3$ = Pengabdian

X4 = Jabatan Struktural

Target $=$ Jumlah Penelitian

c. Studi Pustaka

Studi pustaka merupakan langkah awal dalam penelitian ini, studi pustaka ini dilakukan untuk melengkapi pengetahuan dasar dan teori-teori yang digunakan dalam penelitian ini

d. Praproses

Tahapan yang dikerjakan adalah dengan melakukan perubahan terhadap beberapa tipe data pada atribut dataset dengan tujuan untuk mempermudah pemahaman terhadap isi record, juga melakukan seleksi dengan memperhatikan konsistensi data, missing value.

e. Menentukan model

Hasil dari tahap ini adalah beberapa model jaringan saraf tiruan dengan algoritma Backpropagation untuk menentukan pola 
f. Menguji Hasil Pengolahan Data

Seteleh proses penentuan model selesai, maka dilakukan tahapan uji coba terhadap hasil pengolahan data dengan menggunakan Software Matlab.

g. Memprediksi

Prediksi dilakukan untuk membandingkan jumlah dengan model Jaringan saraf tiruan dengan algoritma Backpropagation yang paling akurat.

h. Mengevaluasi Akhir

Mengevaluasi akhir dilakukan untuk mengetahui apakah testing hasil pengolahan data sesuai dengan yang diharapkan.

\subsubsection{Implementasi Pemerosesan Algoritma Backpropagation}

a. Proses Normalisasi

Proses normalisasi merupakan suatu langkah kerja dalam mememindahkan angka dari kolom menjadi baris dan dari bilangan bulat menjadi pecahan, hal ini dilakukan agar data tadi mudah untuk dilakukan proses perkalian bobot pada matlab karna memiliki angka pecahan atau dinormalisasikan.

Untuk mentransformasikan seluruh data real tersebut, digunakan fungsi rumus (2.1) sebagai berikut.:

$$
x^{1}=\frac{0.8(22-0)}{64-0}+0.1
$$

\section{b. Proses Normalisasi Data Dosen}

Sebelum proses pegolahan data dilakukan, perlu dilakukan proses penetuan masukan (Input) serta target atau hasil yang diinginkan dari proses pengolahan data, berikut data Input dan target berdasarkan data beban kerja dosen yang telah dikumpulkan, sampel yang diambil adalah 40 sampel :

c. Data Pelatihan dan Pengujian

Setalah data Input dan target di tentukan, maka langkah selanjutnya adalah menentukan data pelatihan dan pengujian, berikut data pelatihan dan pengujian :

Tabel 2. Data Pelatihan Beban Kerja Dosen

\begin{tabular}{|c|c|c|c|c|c|}
\hline No & $\mathbf{X 1}$ & $\mathbf{X 2}$ & $\mathbf{X 3}$ & $\mathbf{X 4}$ & Target \\
\hline 1 & 0,3750 & 0,4000 & 0,1125 & 0,2000 & 0,9000 \\
\hline 2 & 0,1000 & 0,1500 & 0,1000 & 0,1000 & 0,1000 \\
\hline 3 & 0,1250 & 0,1375 & 0,1000 & 0,1000 & 0,1000 \\
\hline 4 & 0,1000 & 0,2000 & 0,1000 & 0,1000 & 0,1000 \\
\hline 5 & 0,4250 & 0,3250 & 0,1125 & 0,1625 & 0,7750 \\
\hline 6 & 0,1000 & 0,1500 & 0,1000 & 0,1000 & 0,1000 \\
\hline 7 & 0,1000 & 0,1750 & 0,1000 & 0,1250 & 0,1000 \\
\hline 8 & 0,1750 & 0,4375 & 0,1000 & 0,1000 & 0,1000 \\
\hline 9 & 0,1750 & 0,1500 & 0,1000 & 0,1000 & 0,1000 \\
\hline 10 & 0,2125 & 0,5000 & 0,1125 & 0,2125 & 0,8875 \\
\hline$\ldots$ & $\ldots$ & $\ldots$ & $\ldots$ & $\ldots$ & $\ldots$ \\
\hline 31 & 0,2500 & 0,2625 & 0,1125 & 0,1500 & 0,3250 \\
\hline 32 & 0,1500 & 0,2250 & 0,1125 & 0,1375 & 0,1000 \\
\hline 33 & 0,1000 & 0,2250 & 0,1000 & 0,1000 & 0,1000 \\
\hline 34 & 0,1000 & 0,1750 & 0,1000 & 0,1000 & 0,1000 \\
\hline
\end{tabular}




\begin{tabular}{|c|c|c|c|c|c|}
\hline No & X1 & X2 & X3 & X4 & Target \\
\hline 35 & 0,2000 & 0,4125 & 0,1000 & 0,1000 & 0,1000 \\
\hline 36 & 0,1000 & 0,1500 & 0,1000 & 0,1000 & 0,1000 \\
\hline 37 & 0,3625 & 0,3500 & 0,1000 & 0,1125 & 0,2000 \\
\hline 38 & 0,4250 & 0,4375 & 0,1125 & 0,1125 & 0,2375 \\
\hline 39 & 0,1500 & 0,2750 & 0,1125 & 0,1000 & 0,1000 \\
\hline 40 & 0,2250 & 0,2750 & 0,1000 & 0,1000 & 0,1375 \\
\hline
\end{tabular}

d. Perancangan Manual Jaringan saraf tiruan

Tahap berikutnya yaitu merancang arsitektur JST backpropagation. Dalam hal ini menggunakan beberapa model jaringan multi-layer (banyak lapisan) yang digunakan untuk mendapatkan arsitektur terbaik adalah 4-4-1, 4-5-1, 4-10-1, 4-25-1 dan 4-5-10-1. Model sampel arsitektur 4-4-1 dapat dilihat pada gambar dibawah ini.

Gambar 2. Arsitektur Jaringan Backpropagation

Perhitungan manual hanya dilakukan pada sampel data Input, berikut tahapan-tahapan yang dilakukan :

Tahap initialitation

a. Tahapan dalam proses inisialisasi ini adalah menginisialisasi data Input, bobot dari Input ke pada hiden layer lalu ke output layer. Yang akan menjadi nilai Input adalah X1-Xn, dengan menggunakan :

Learning Default $=0,01$ Epocs $=500.000 \mathrm{Goal}=0,001$

Variabel Input terdiri dari

$\mathrm{X} 1=0,375$

$\mathrm{X} 2=0,400$

$\mathrm{X} 3=0,1125$

$\mathrm{X} 4=0,200$

b. Berikan nilai bobot dari Input ke hidden layer. Pada tabel 4.10 dan 4.11 akan terlihat bobot dari Input layer ke hidden layer, dari hiden layer ke output yang penulis ambil dari Sistem Matlab 6.1.

Tabel 3. Bobot yang diberikan dari Input layer ke hidden layer

\begin{tabular}{|r|r|r|r|}
\hline & \multicolumn{1}{|c|}{ V1 } & \multicolumn{1}{c|}{ V2 } & \multicolumn{1}{c|}{ V3 } \\
\hline $\mathbf{X 1}$ & 22,3942 & $-8,8880$ & 4,6746 \\
\hline $\mathbf{X 2}$ & $-0,6044$ & 11,2108 & 9,9383 \\
\hline $\mathbf{X 3}$ & $-56,3097$ & $-413,8487$ & 365,6189 \\
\hline $\mathbf{X 4}$ & $-7,9474$ & 11,0239 & 36,8994 \\
\hline $\mathbf{1}$ & $-2,1424$ & 40,9385 & $-45,3846$ \\
\hline
\end{tabular}


Tabel 4. Bobot yang diberikan dari hidden layer ke ouput layer

\begin{tabular}{|c|c|}
\hline & \multicolumn{1}{|c|}{ L } \\
\hline $\mathbf{Z 1}$ & 0,8436 \\
\hline $\mathbf{Z 2}$ & 0,4764 \\
\hline $\mathbf{Z 3}$ & $-0,6475$ \\
\hline $\mathbf{1}$ & -0.1886 \\
\hline
\end{tabular}

Tahap 1: Perhitungan Maju :

Perhitungan maju adalah perhitungan nilai output dari unit tersembunyi atau hidden layer, sebagaimana rumus yang telah dijelaskan pada landasan teori :

z_net1 $=\mathrm{V} 1+(\mathrm{X} 1 * \mathrm{~V} 11)+(\mathrm{X} 2 * \mathrm{~V} 21+(\mathrm{X} 3 * \mathrm{~V} 31)+(\mathrm{X} 4 * \mathrm{~V} 41)=-2,1424+(22,3942 *$ $0,3750)+\left(-0,6044^{*} 0,4000\right)+(-56,3097 * 0,1125)+(-7,9474 * 0,2000)=-1,9107$ z_net2 $=-2,2634$

z_net3 $=8,8557$

1) Kemudian dilanjutkan dengan menghitung nilai keluaran dengan menggunakan fungsi aktivasi yang dipilih, di mana fungsi aktivasi yang digunakan adalah fungsi sigmoid biner yang mempunyai persamaan, sesuai dengan rumus pada (2.4.a) :

a. $\mathrm{z} 1=\operatorname{sigmoid}[-1,9107]=\frac{1}{1+e^{(-1,9107)}}=0,1289$

b. $\mathrm{z} 1=$ sigmoid $[-2,2634]=\frac{1}{1+e^{(-2,2634)}}=0,0942$

c. $\mathrm{z} 1=\operatorname{sigmoid}[8,8557]=\frac{1}{1+e^{(8,8557)}}=1,0000$

2) Menghitung nilai output pada unit yk $(\mathrm{k}=1,2,3, \ldots, \mathrm{m})$ dengan menggunakan nilai bobot-nya, yang dijelaskan pada rumus $(2.4 \mathrm{~b}): \mathrm{Y}_{\text {ink }}=\mathrm{N}_{\text {JII }}=-0,1886+(0,1289071$ $* 08436)+(0,0942 * 0.4764)+(1,0000 *-0.6475)=-0,6824$

Kemudian dihitung nilai Output dengan menggunakan fungsi aktivasi : sigmoid $[-0,6824]=\frac{1}{1+e^{(-0,6824)}}=0,33573$

Tahap 2: Perhitungan Mundur:

1) Untuk tiap unit keluaran $(y k, \mathrm{k}=1, . ., \mathrm{m})$ menerima pola target yang bersesuaian dengan pola masukan, dan kemudian dihitung informasi kesalahan Hitung faktor $\delta$ diunit keluaran berdasarkan kesalahan setiap unit keluaran yk, rumus yang digunakan berdasarkan rujukan pada (2.5a)

$$
\delta 1=(0,9000-0,33573) * 0,33573 *(1-0,33573)=0,1258409
$$

2) Suku perubahan bobot Wjk dilakukan perhitungan (yang akan digunakan untuk merubah bobot $\mathrm{Wjk}$ ) dengan laju pelatihan learning rate $\alpha=0.2$, rumus yang digunakan berdasarkan rujukun pada (2.5b)

$$
\begin{aligned}
& \Delta \mathrm{W} 10=0,2 * 0,1258 * 1=0,0251 \\
& \Delta \mathrm{W} 11=0,2 * 0,1258 *-1,9107=-0,0481 \\
& \Delta \mathrm{W} 12=0,2 * 0,1258 *-2,2634=-0,057 \\
& \Delta \mathrm{W} 13=0,2 * 0,1258 * 8,8557=0.2228
\end{aligned}
$$

3) Untuk setiap (Zj, j=1,..,p) dihitung delta masukan yang berasal dari neuron pada layer di atasnya, berdasarkan rujukan pada (2.6) :

$\delta \_$net $1=0,1258 * 0,8436=0,1061$ 
$\delta \_n e t 2=0,1258 * 0,4764=0,5995$

$\delta \_n e t 3=0,1258 *-0,6475=-0,0815$

4) Kemudian nilai tersebut dikalikan dengan nilai turunan dari fungsiaktivasi untuk menghitung informasi kesalahan, berdasarkan rujukan pada (2.7) :

$$
\begin{aligned}
& \delta 1=0,1061 * 0,1289 *(1-0,1289)=0,011920 \\
& \delta 2=0,5995 * 0,0942 *(1-0,0942)=0,00511 \\
& \delta 3=-0,0815 * 1,0000 *(1-1,0000)=-1,16133
\end{aligned}
$$

5) Hitung koreksi nilai bobot yang kemudian digunakan untuk memperbaharui vij, berdasarkan rujukan pada (2.8) :

$$
\begin{aligned}
& \Delta v 11=0,3750 * 0,2 * 0,01192=0,01192 \\
& \Delta v 21=0,3750 * 0,2 * 0,00511=-0,005115 \\
& \Delta v 31=0,3750 * 0,2 *-1,16133=-1,16133
\end{aligned}
$$

Perhitungan dilanjutkan, sehingga di dapatkan data sebagai berikut :

Tabel 5. Koreksi Nilai Bobot

\begin{tabular}{|c|c|c|c|}
\hline Baru & V1 & V2 & V3 \\
\hline $\mathbf{X 1}$ & 0,00944 & $-0,0088$ & $-0,0024$ \\
\hline $\mathbf{X 2}$ & 0,00944 & $-0,0088$ & $-0,0024$ \\
\hline $\mathbf{X 3}$ & 0,00944 & $-0,0088$ & $-0,0024$ \\
\hline $\mathbf{X 4}$ & 0,00944 & $-0,0088$ & $-0,0024$ \\
\hline
\end{tabular}

$\mathrm{W} 1(\mathrm{baru})=0.8436+-0,0481=0.7955$

W2 $($ baru $)=0.4764+-0,057=0.4194$

W3 $($ baru $)=-0.6475+0.2228=-0.4246$

Bobot garis mengalami perubahan pada saat terhubung ke hiden layer, berdasarkan rujukan pada (2.11):

V11 $($ baru $)=0,01192+22,3942=22,3951$

V21 $($ baru $)=-0,005115+-8,8880=-8,8968$

V21 (baru) $=-1,16133+4,6746=4,6746$

Tabel 6. Perubahan Bobot Akhir Pada $\mathrm{P}=1$ Dari Input Ke Hiden Layer

\begin{tabular}{|c|r|r|r|}
\hline Baru & \multicolumn{1}{|c|}{ V1 } & \multicolumn{1}{c|}{ V2 } & \multicolumn{1}{c|}{ V3 } \\
\hline X1 & 22,3854 & $-8,8968$ & 4,67216 \\
\hline $\mathbf{X 2}$ & $-0,595$ & 11,202 & 9,93586 \\
\hline $\mathbf{X 3}$ & $-56,3$ & $-413,86$ & 365,616 \\
\hline $\mathbf{X 4}$ & $-7,938$ & 11,0151 & 36,897 \\
\hline
\end{tabular}

Tabel 7. Perubahan Bobot Akhir Pada P=1 Dari Hidden Ke Output Layer

\begin{tabular}{|c|c|}
\hline & \multicolumn{1}{|c|}{$\mathbf{L}$} \\
\hline $\mathbf{Z 1}$ & 0,7955 \\
\hline $\mathbf{Z 2}$ & 0,4194 \\
\hline $\mathbf{Z 3}$ & $-0,4246$ \\
\hline $\mathbf{1}$ & $-0,1634$ \\
\hline
\end{tabular}

Setelah hasil perubahan bobot dan bias pada proses iterasi pertama selesai dilakukan maka akan menghasilkan nilai perubahan bobot dan bias yang baru melalui proses pelatihan. Proses pelatihan jaringan akan dilanjutkan secara berkelanjutan sampai nantinya menghasilkan nilai output dan juga nilai error yang 
terkecil. Untuk hasil dari iterasi pertama dari data baris pertama dari perhitungan manual berikut dengan output sebagai berikut :

$\mathrm{Y}_{\text {ink }}=\mathrm{N}_{\mathrm{JII}}=-0,1886+(0,1289071 * 08436)+(0,0942 * 0.4764)+(1,0000 *-0.6475)$ $=-0,6824$

Kemudian dihitung nilai Output dengan menggunakan fungsi aktivasi :

sigmoid $[-0,6824]=\frac{1}{1+e^{(-0,6824)}}=0,33573$

Setelah itu hasil output jst dikurangkan dengan target untuk menghitung margin error : Output Jst - Target

$0,33573-0,9000=0,56427$

Setelah terlihat dari hasil nilai iterasi pertama dengan nilai 0,56427 dapat menjelaskan bahwa perlu adanya pembalajaran data untuk memaksimalkan performance data yang diuji. Tidak sampai disitu saja dilakukan juga proses pengujian dengan pola yang sudah di tentukan, proses ini berguna untuk mendapatkan keakuratan antara pelatihan dan pengujian sehingga didapatkan kesimpulan korelasi penigkatan iklim penelitian dengan beban kerja dosen. Maka Untuk mempercepat proses dari pemecahan masalah dari penelitian ini, maka penulis menggunakan sebuah alat bantu program berupa Software Matlab 6.1, karena software Matlab 6.1 didesain dengan sedemikian rupa dengan mengadaptasi dari algoritma yang penulis gunakan pada penelitian ini.

\section{HASIL DAN PEMBAHASAN}

\subsection{Pembahasan}

\subsubsection{Pelatihan dan Pengujian dengan Software Matlab 6.1}

Matlab (matrix laboratory) merupakan salah satu perangkat lunak yang dirancang khusus sebagai solusi untuk mengerjakan permasalahan yang berkaitan dengan matematika.

1. Tampilan command window yang digunakan untuk membuat dan mengetik semua perintah pelatihan dan pengujian Backpropagation adalah sebagai berikut :

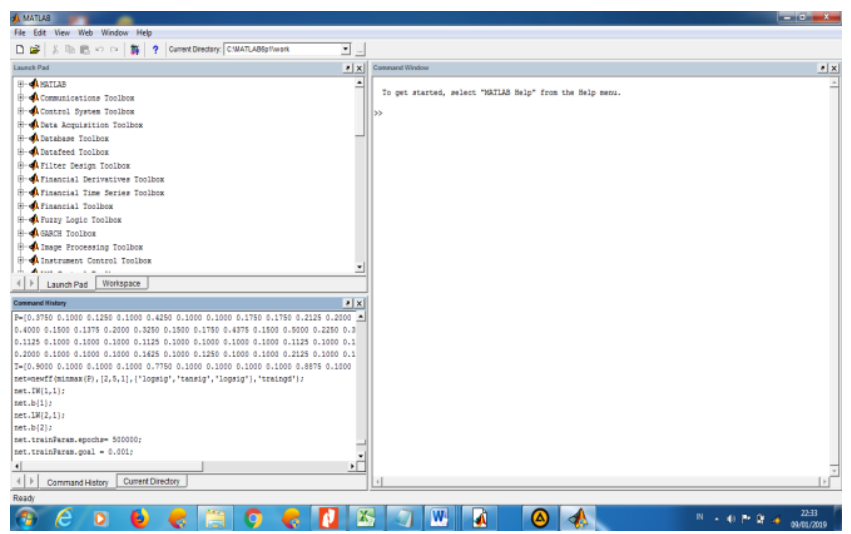

Gambar 3. Command Window

2. Input Data Training

Inputan data Training yang sudah di normalisasi yang akan dihitung didalam tool Matlab 6.1. 


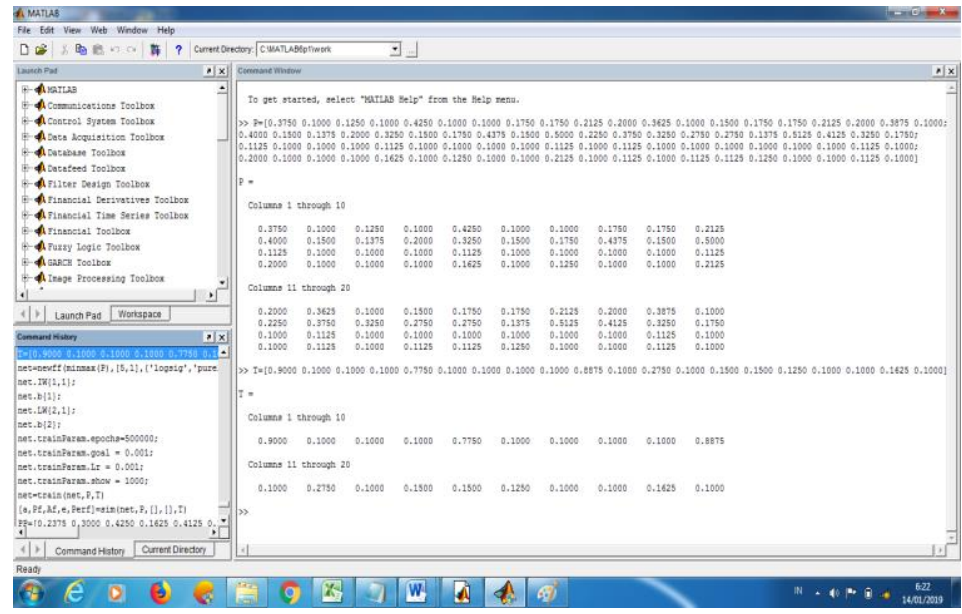

Gambar 4. Data Training

3. Koding Data Training

Dari gambar berikut dapat dilihat koding dalam menTraining data.

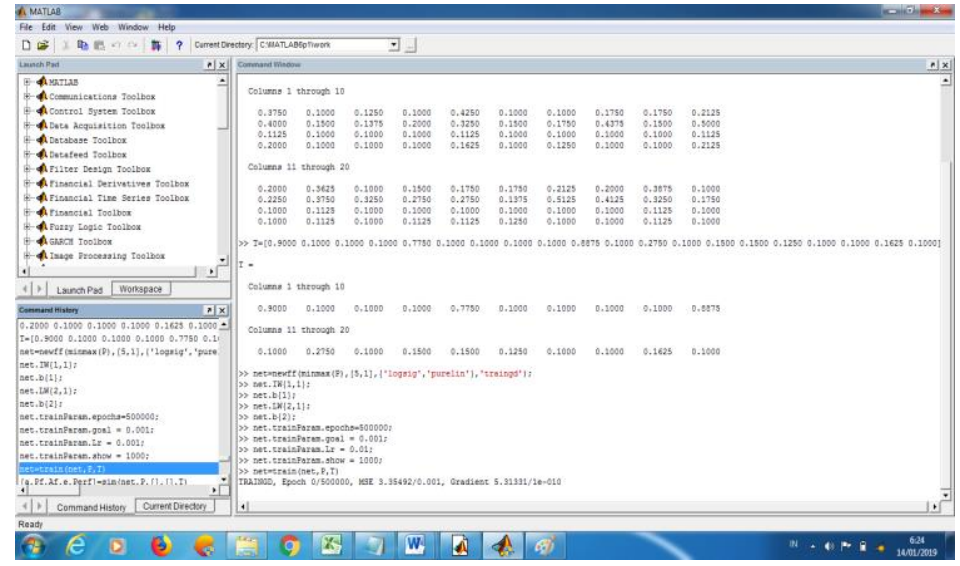

Gambar 5. Koding Data Training

4. Proses Training

Dari gambar dibawah dapat dijelaskan bahwa proses Training data Backpropagation pada Matlab 6.1.

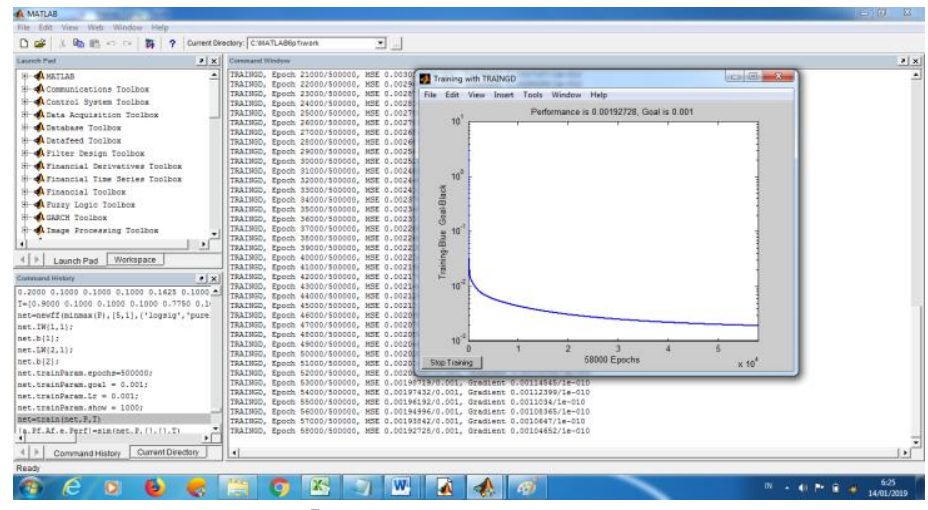

Gambar 6. Proses Training

Penerapan JST untuk Mengukur Korelasi Beban Kerja Dosen(Putrama Alkhairi)| 596 
5. Hasil Output Training Data

Gambar dibawah menjelaskan bahwa hasil output dari Training data yang sudah dilakuakan oleh matlab melalui pembelajaran data.

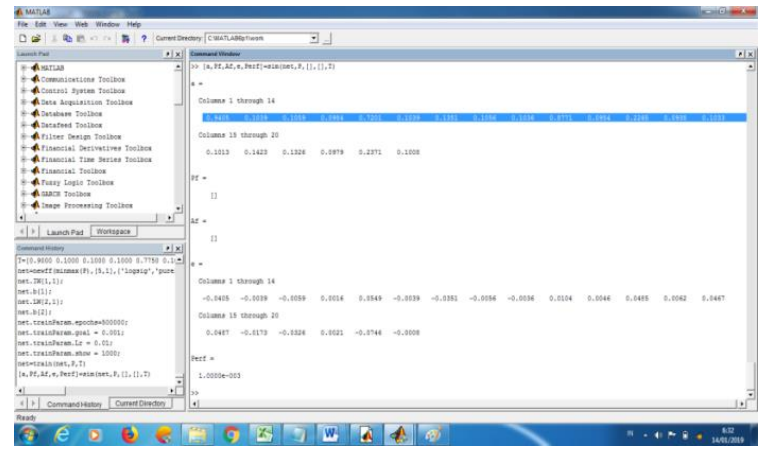

Gambar 7. Output Proses Training

6. Inputan Testing Data

Inputan data Testing yang sudah di normalisasi yang akan dihitung didalam tool Matlab 6.1

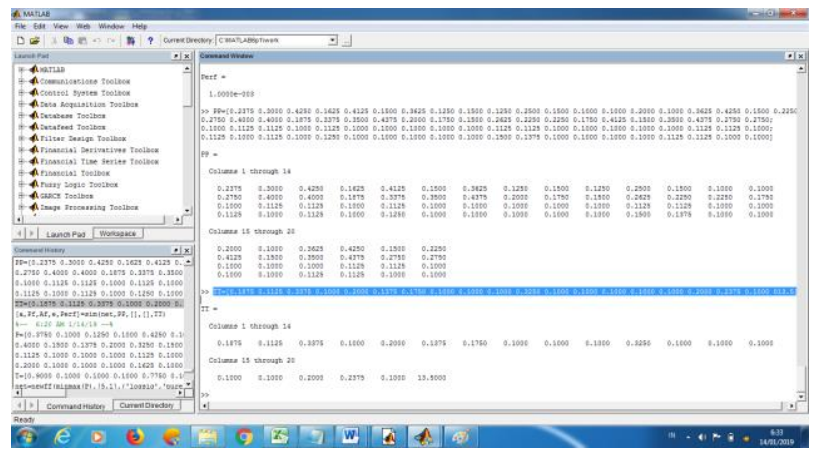

Gambar 8. Input Testing Data

7. Output Testing Data

Gambar dibawah menjelaskan bahwa hasil output dari Testing data yang sudah dilakuakan oleh matlab.

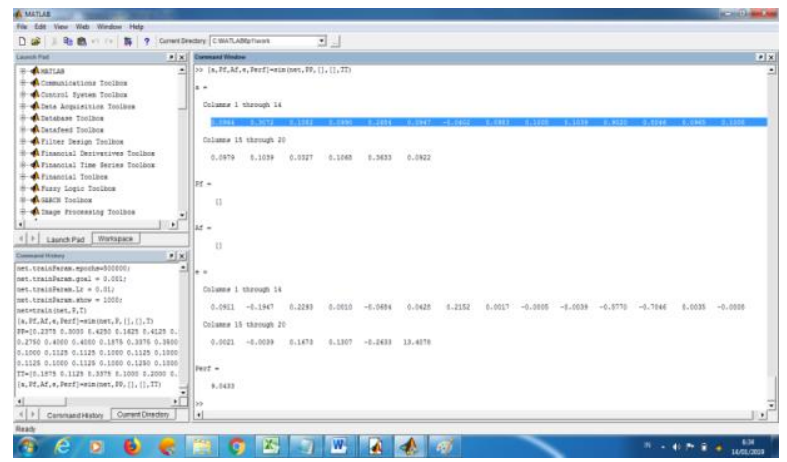

Gambar 9. Output Testing Data

Hasil percobaan menunjukkan bahwa Jaringan saraf tiruan dengan Algoritma Backpropagation yang sudah dilatih dan diuji dengan baik akan memberikan Penerapan JST untuk Mengukur Korelasi Beban Kerja Dosen(Putrama Alkhairi) | 597 
keluaran yang masuk akal jika diberi masukan yang serupa dengan pola yang dipakai untuk pelatihan dan pengujian. Sifat generalisasi ini membuat pelatihan dan pengujian lebih efisien karena tidak perlu dilakukan pada semua data. Jaringan saraf tiruan dengan Algoritma Backpropagation dibentuk dengan membuat generalisasi aturan pelatihan dan pengujian dalam model Windrow-Hooff dengan cara menambahkan lapisan tersembunyi (hidden layer). Standar Algoritma Backpropagation menggunakan algoritma penurunan gradien (gradien descent). variasi terhadap model standar dilakukan dengan mengganti algoritmanya dengan algoritma lain.

\subsubsection{Input Data Real}

Tahap Normalisasi dilakukan Setelah data Input dan real dimasukkan dalam tools oleh user ke Ms.Excel, maka tools akan melakukan proses normalisasi sesuai perintah user.

\subsection{Hasil}

Dari hasil pengujian data beban kerja dosen diatas dapat kita lihat pada arsitektur 4-2-5-1 yang menunjukan dari target dikurang dengan output jst bahwa SSE 0,02000 yang menunjukan bahwa adanya korelasi antara beban kerja dosen dengan peningkatan jumlah publikasi sebagai target. Dari data yang didapat, bahwa perfomance perhitungan jaringan saraf tiruan dengan Algoritma Backpropagation adalah $90 \%$. Dapat dilihat dengan perbandingan target yang diinginkan dengan target prediksi. Jumlah peningkatan publikasi dengan tingkat beban kerja dosen berdasarkan tabel 4.18. menunjukan bahwa peningkatan publikasi pada tahun 2018 di STIKOM Tunas Bangsa Pematangsiantar terletak pada skala minim. Dan jaringan saraf tiruan dengan menggunakan algoritma backpropogation dapat diterapkan dalam menganalisa korelasi antara beban kerja terhadap peningkatan jumlah publikasi dengan menentukan model arsitektur terbaik dari serangkain proses training dan testing yang dilakukan.

\subsubsection{Pelatihan dan Pengujian Arsitektur 4-2-5-1}

Berikut adalah hasil pelatihan dan pengujian dengan 40 data untuk arsitektur 4-2-5-1. Adapun parameter yang digunakan adalah

Koding Pelatihan Koding Pengujian




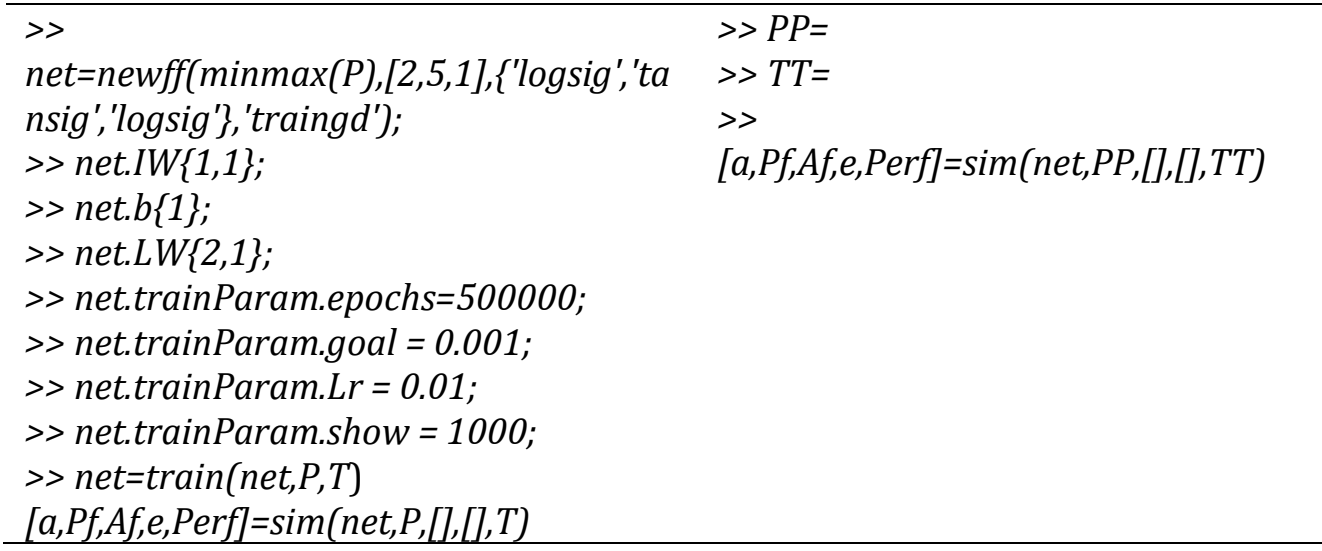

Setelah dilakukan perulangan maka ditemukan error minimum pada epoch 99540 Seperti pada gambar 11.

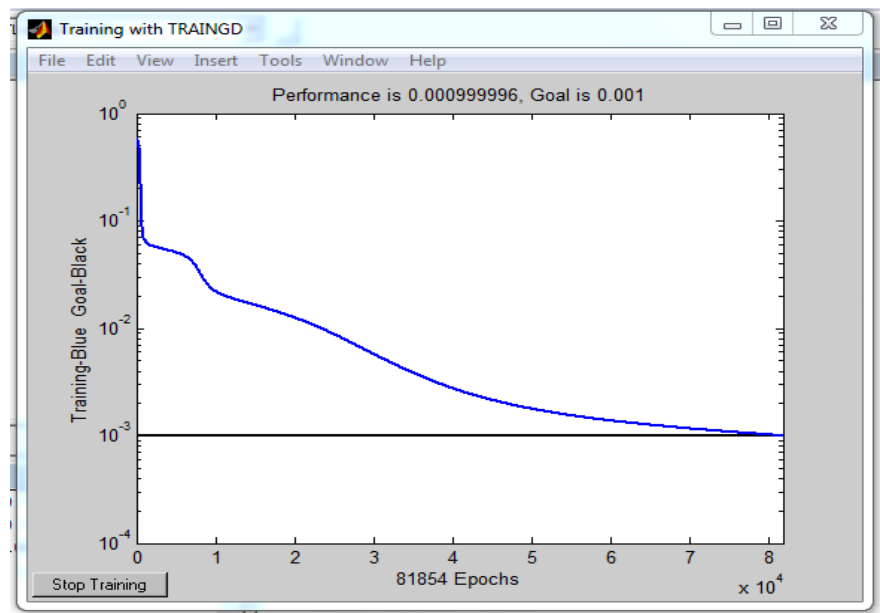

Gambar 11. Pelatihan Arsitektur 4-2-5-1 Mencapai Goal

Untuk hasil yang lebih rinci dan mengetatahui output dan error dapat dilihat pada tabel 10 .

Tabel 8. Hasil Pelatihan dengan Model 4-2-5-1

\begin{tabular}{|c|c|c|c|c|c|}
\hline No & Target & Output JST & Error & SSE & Hasil \\
\hline 1 & 0,9000 & 0,8514 & 0,04860 & 0,00236 & 1 \\
\hline 2 & 0,1000 & 0,1173 & $-0,01730$ & 0,00030 & 1 \\
\hline 3 & 0,1000 & 0,1131 & $-0,01310$ & 0,00017 & 1 \\
\hline 4 & 0,1000 & 0,1172 & $-0,01720$ & 0,00030 & 1 \\
\hline 5 & 0,7750 & 0,7924 & $-0,01740$ & 0,00030 & 1 \\
\hline 6 & 0,1000 & 0,1173 & $-0,01730$ & 0,00030 & 1 \\
\hline 7 & 0,1000 & 0,1010 & $-0,00100$ & 0,00000 & 1 \\
\hline 8 & 0,1000 & 0,1072 & $-0,00720$ & 0,00005 & 1 \\
\hline 9 & 0,1000 & 0,1065 & $-0,00650$ & 0,00004 & 1 \\
\hline 10 & 0,8875 & 0,8794 & 0,00810 & 0,00007 & 1 \\
\hline 11 & 0,1000 & 0,1044 & $-0,00440$ & 0,00002 & 1 \\
\hline 12 & 0,2750 & 0,2069 & 0,06810 & 0,00464 & 0 \\
\hline 13 & 0,1000 & 0,1170 & $-0,01700$ & 0,00029 & 1 \\
\hline 14 & 0,1500 & 0,1024 & 0,04760 & 0,00227 & 1 \\
\hline 15 & 0,1500 & 0,1011 & 0,04890 & 0,00239 & 1 \\
\hline
\end{tabular}

Penerapan JST untuk Mengukur Korelasi Beban Kerja Dosen(Putrama Alkhairi) 599 


\begin{tabular}{|c|c|c|c|c|c|}
\hline No & Target & Output JST & Error & SSE & Hasil \\
\hline 16 & 0,1250 & 0,0985 & 0,02650 & 0,00070 & 1 \\
\hline 17 & 0,1000 & 0,1060 & $-0,00600$ & 0,00004 & 1 \\
\hline 18 & 0,1000 & 0,1053 & $-0,00530$ & 0,00003 & 1 \\
\hline 19 & 0,1625 & 0,2363 & $-0,07380$ & 0,00545 & 1 \\
\hline \multirow[t]{3}{*}{20} & 0,1000 & 0,1172 & $-0,01720$ & 0,00030 & 1 \\
\hline & & & & 0,02000 & \multirow{2}{*}{95} \\
\hline & & & MSE & 0,00100015 & \\
\hline
\end{tabular}

Tabel 9. Hasil Pengujian dengan Model 4-2-5-1

\begin{tabular}{|c|c|c|c|c|c|}
\hline No & Target & Output JST & Error & SSE & Hasil \\
\hline 1 & 0,1875 & 0,09960 & 0,08790 & 0,00773 & 0 \\
\hline 2 & 0,1125 & 0,15330 & $-0,04080$ & 0,00166 & 1 \\
\hline 3 & 0,3375 & 0,29280 & 0,04470 & 0,00200 & 1 \\
\hline 4 & 0,1000 & 0,10780 & $-0,00780$ & 0,00006 & 1 \\
\hline 5 & 0,2000 & 0,46310 & $-0,26310$ & 0,06922 & 1 \\
\hline 6 & 0,1375 & 0,10940 & 0,02810 & 0,00079 & 1 \\
\hline 7 & 0,1750 & 0,14090 & 0,03410 & 0,00116 & 1 \\
\hline 8 & 0,1000 & 0,11300 & $-0,01300$ & 0,00017 & 1 \\
\hline 9 & 0,1000 & 0,10940 & $-0,00940$ & 0,00009 & 1 \\
\hline 10 & 0,1000 & 0,11310 & $-0,01310$ & 0,00017 & 1 \\
\hline 11 & 0,3250 & 0,84300 & $-0,51800$ & 0,26832 & 1 \\
\hline 12 & 0,1000 & 0,32550 & $-0,22550$ & 0,05085 & 1 \\
\hline 13 & 0,1000 & 0,1171 & $-0,01710$ & 0,00029 & 1 \\
\hline 14 & 0,1000 & 0,11720 & $-0,01720$ & 0,00030 & 1 \\
\hline 15 & 0,1000 & 0,10530 & $-0,00530$ & 0,00003 & 1 \\
\hline 16 & 0,1000 & 0,11730 & $-0,01730$ & 0,00030 & 1 \\
\hline 17 & 0,2000 & 0,11500 & 0,08500 & 0,00723 & 0 \\
\hline 18 & 0,2375 & 0,29210 & $-0,05460$ & 0,00298 & 1 \\
\hline 19 & 0,1000 & 0,11120 & $-0,01120$ & 0,00013 & 1 \\
\hline 20 & 0,1375 & 0,10320 & 0,03430 & 0,00118 & 1 \\
\hline & & & & 0,41465 & 90 \\
\hline & & & MSE & 0,02073255 & \\
\hline
\end{tabular}

Matlab (matrix laboratory) merupakan salah satu perangkat lunak yang dirancang khusus sebagai solusi untuk mengerjakan permasalahan yang berkaitan dengan matematika.

\section{KESIMPULAN}

Berdasarkan hasil dan pembahasan yang telah dilakukan, maka penulis mengambil beberapa kesimpulan:

1. Bahwa jaringan saraf tiruan dengan menggunakan algoritma backpropogation dapat diterapkan dalam menganalisa korelasi antara beban kerja dan peningkatan jumlah publikasi dengan menentukan model arsitektur terbaik dari serangkain proses training dan testing yang dilakukan

2. Dengan menggunakan 5 variabel yakni : Semester Ganjil (X1), Semester Genap (X2), Jumlah pengabdian (X3), Jabatan Struktur (X4) dan Jumlah Publikasi (X5) diperoleh model arsitektur terbaik dari 5 arsitektur (4-4-1; 4-5-1; 4-10-1; 4-25-1; dan 4-5-10-1) diperoleh model arsitektur terbaik (4-2-5-1) dengan MSE 0.020732548 , epoch 81854 denga tingkat akurasi 90\%. 


\section{DAFTAR PUSTAKA}

[1] W. Budiharto and D. Suhartono, ARTIFICIAL INTELLIGENCE KONSEP DAN PENERAPANNYA, ANDI Yogya. Yogyakarta, 2014.

[2] Y. Nuraeni, "Penerapan Jaringan Syaraf Tiruan Untuk Mengukur Tingkat Korelasi Antara Nem Dengan Ipk Kelulusan Mahasiswa," TELKOMNIKA (Telecommunication Comput. Electron. Control., vol. 7, no. 3, p. 195, 2009.

[3] T. Dalgleish et al., Jaringan Syaraf Tiruan (Neural Network), vol. 136, no. 1. 2014.

[4] R. N. Putri, D. Setiawan, and E. Mufadli, "Analisa Korelasi Peningkatan Jumlah Penelitian Dengan Tingkat Beban Kerja Dosen Menggunakan Metode Backpropagation," 2016.

[5] Solikhun and M. Safii, "Jaringan Saraf Tiruan Untuk Memprediksi," J. Sains Komput. Inform., vol. 1, no. 1, pp. 24-36, 2017.

[6] Undang-Undang, "UNDANG-UNDANG REPUBLIK INDONESIA NOMOR 14 TAHUN 2017 REVISI TAHUN 2005 TENTANG GURU DAN DOSEN," 2017.

[7] K. Djoko, "Pedoman Beban Kerja Dosen dan Evaluasi Pelaksanaan Tridharma Perguruan Tinggi. Direktorat Jenderal Pendidikan Tinggi Departemen Pendidikan Nasional 2010," p. 20, 2010.

[8] P. Pangastuti, "Untuk Mengukur Tingkat Korelasi Prestasi Mahasiswa ( Studi Kasus Pada Universitas Dian Nuswantoro Semarang )," 2014.

[9] T. Riyanto, "Akuntabilitas Finansial dalam Pengelolaan Alokasi Dana Desa (ADD) di Kantor Desa Perangkat Selatan Kecamatan Marangkayu Kabupaten Kutai Kartenegara," eJournal Adm. Negera, vol. 3, no. 1, pp. 119-130, 2015.

[10] Agus Perdana Windarto, "Implementasi Jst Dalam Menentukan Kelayakan Nasabah Pinjaman Kur Pada Bank Mandiri Mikro Serbelawan Dengan Metode Backpropogation," J-SAKTI (Jurnal Sains Komput. dan Inform., vol. 1, no. 1, pp. 12-23, 2017.

[11] A. P. Windarto, L. S. Dewi, and D. Hartama, "Implementation of Artificial Intelligence in Predicting the Value of Indonesian Oil and Gas Exports With BP Algorithm," Int. J. Recent Trends Eng. Res., vol. 3, no. 10, pp. 1-12, 2017.

[12] Z. A. Matodang, "Jaringan Syaraf Tiruan Dengan Algoritma Backpropagtion Untuk Penentuan Kelulusan Sidang Skripsi," Pelita Inform. Budi Darma, vol. 4, no. 1, pp. 84-93, 2013.

[13] Y. A. Lesnussa, S. Latuconsina, and E. R. Persulessy, "Aplikasi Jaringan Saraf Tiruan Backpropagation untuk Memprediksi Prestasi Siswa SMA ( Studi kasus : Prediksi Prestasi Siswa SMAN 4 Ambon )," J. Mat. Integr., vol. 11, no. 2, pp. 149-160, 2015.

[14] N. M. Sukarno, P. W. Wirawan, and S. Adhy, "Perancangan dan implementasi jaringan saraf tiruan," vol. 5, pp. 9-18, 2013.

[15] L. Handayani and M. Adri, "Penerapan JST ( Backpropagation ) untuk Prediksi Curah Hujan ( Studi Kasus : Kota Pekanbaru ),” no. November, pp. 238-247, 2015.

[16] M. R. Munandar, E. S. Astuti, and M. S. Hakam, "Pengaruh Keelamatan, Kesehatan Kerja (K3) dann Insentif terhadap Motivasi dan Kinerja Karyawan (Studi pada Pekerja Bagian Produksi PT. Sekawan Karyatama Mandiri Sidoarjo)," J. Adm. Bisnis, vol. 9, no. 1, pp. 1-9, 2014.

[17] A. Wanto, "Analisis Prediksi Indeks Harga Konsumen Berdasarkan Kelompok Kesehatan Dengan Menggunakan Metode Backpropagation," J. Penelit. Tek. Inform., vol. 2, no. 2, pp. 3744, 2017. 